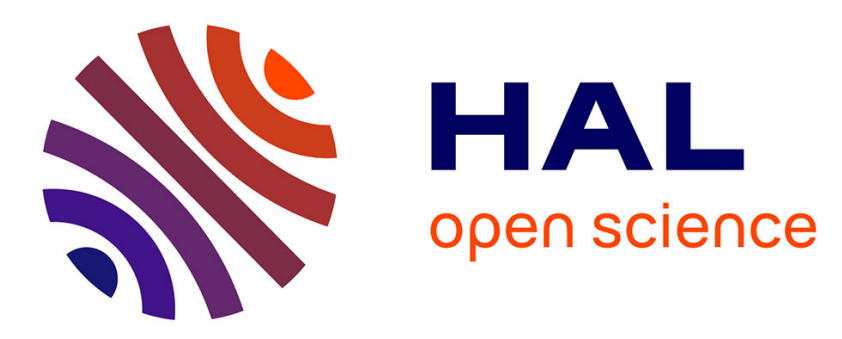

\title{
Salinity variability in satellite subpixels: impact on satellite in-situ comparisons
}

Clovis Thouvenin-Masson, Jacqueline Boutin, Jean-Luc Vergely, Dimitry Khvorostyanov, Xavier Perrot, Gilles Reverdin

\section{- To cite this version:}

Clovis Thouvenin-Masson, Jacqueline Boutin, Jean-Luc Vergely, Dimitry Khvorostyanov, Xavier Perrot, et al.. Salinity variability in satellite subpixels: impact on satellite in-situ comparisons. EGU General Assembly 2021, EGU, Apr 2021, online, France. 10.5194/egusphere-egu21-1205 . hal-03216413

\section{HAL Id: hal-03216413 \\ https://hal.sorbonne-universite.fr/hal-03216413}

Submitted on 4 May 2021

HAL is a multi-disciplinary open access archive for the deposit and dissemination of scientific research documents, whether they are published or not. The documents may come from teaching and research institutions in France or abroad, or from public or private research centers.
L'archive ouverte pluridisciplinaire HAL, est destinée au dépôt et à la diffusion de documents scientifiques de niveau recherche, publiés ou non, émanant des établissements d'enseignement et de recherche français ou étrangers, des laboratoires publics ou privés. 
EGU21-1205, updated on 04 May 2021

https://doi.org/10.5194/egusphere-egu21-1205

EGU General Assembly 2021

(c) Author(s) 2021. This work is distributed under

the Creative Commons Attribution 4.0 License.

\section{Salinity variability in satellite subpixels: impact on satellite in-situ comparisons.}

Clovis Thouvenin-Masson ${ }^{1}$, Jacqueline Boutin ${ }^{2}$, Jean-Luc Vergely ${ }^{3}$, Dimitry Khvorostyanov ${ }^{2}$, Xavier Perrot $^{2}$, and Gilles Reverdin ${ }^{2}$

${ }^{1}$ CNRS, Sorbonne université, IRD, MNHN - CNES - LOCEAN/IPSL, Paris, France

${ }^{2}$ CNRS, Sorbonne université, IRD, MNHN - LOCEAN/IPSL, Paris, France

${ }^{3}$ ACRI-ST, Guyancourt, France

Sea Surface Salinity (SSS) are retrieved from SMOS and SMAP L-band radiometers at a spatial resolution of about $50 \mathrm{~km}$.

Traditionally, satellite SSS products validation is based on comparisons with in-situ near surface salinity measurements.

In-situ measurements are performed on moorings, argo floats and along ship tracks[JB1], which provide punctual or one-dimensional (along ship tracks) estimations of the SSS.

The sampling difference between one-dimensional or punctual in-situ measurements and twodimensional satellite products results in a sampling error that must be separated from measurement errors for the validation of satellite products.

We use a small-scale resolution field ( $1 / 12^{\circ}$ Mercator Global Ocean Physics Analysis and Forecast) to estimate the expected sampling error of each kind of in-situ measurements, by comparing punctual, [JB2] one-dimensional and two-dimensional SSS variability.

The better understanding of sampling errors allows a more accurate validation of satellite SSS and of the errors estimated by satellite retrieval algorithms. The improvement is quantified by considering the standard deviation of satellite minus in-situ salinities differences normalized by the sampling and retrieval errors. This quantity should be equal to one if all the error contributions are correctly considered. This methodology will be applied to SMOS SSS and to 
merged SMOS and SMAP SSS products. 